TTR

Traduction, terminologie, rédaction

\title{
Underground Games: Surface Translation and the Grotesque
}

\section{Ryan Fraser}

Volume 29, numéro 2, 2e semestre 2016

Translation and Power: Countertactics

La traduction et le pouvoir : la contre-tactique

URI : https://id.erudit.org/iderudit/1051015ar

DOI : https://doi.org/10.7202/1051015ar

Aller au sommaire du numéro

\section{Éditeur(s)}

Association canadienne de traductologie

ISSN

0835-8443 (imprimé)

1708-2188 (numérique)

Découvrir la revue

Citer cet article

Fraser, R. (2016). Underground Games: Surface Translation and the Grotesque. TTR, 29(2), 99-128. https://doi.org/10.7202/1051015ar

\section{Résumé de l'article}

Souvent citée par les théoriciens pour des raisons contradictoires, la " traduction de surface » a un statut ambivalent en traductologie - chose peu étonnante étant donné que cette forme eccentrique-comique de traduction se veut " ambivalente » autant dans sa composition que dans sa lecture. Cependant, la théorie a marqué des progrès vers une meilleure compréhension de la traduction de surface au moment où Jean-Jacques Lecercle (1990) l'a conçue comme une forme in extremis d'interférence linguistique. Je me laisserai orienter par cette conception en proposant ici que cette pratique serait en tous points comparable au style ornemental classique et médiéval nommé « grotesque " par l'histoire des beaux-arts. Je présente ici la première étude traductologique à inscrire la traduction de surface dans la tradition du grotesque. Les points de comparaison sont au nombre de cinq : 1) la traduction de surface et les représentations dites " grotesques » sont créées par le mélange proscrit de matériaux incompatibles; 2) les deux impliquent, en plus, la notion d'une marge et d'un jeu centre-périphérie; 3) les deux sont informés par l'esthétique du comique, pervers, monstrueux; 4) les explications qu'ils génèrent sont fondées presque sans exception dans l'automatisme du langage et de la pensée; 5) les deux priorisent manifestement une lecture dans "l'ambivalence". 


\title{
Underground Games: Surface Translation and the Grotesque
}

\author{
Ryan Fraser \\ University of Ottawa
}

\begin{abstract}
Referenced by theory for seemingly contradictory purposes, the practice of "surface translation" has an ambivalent status within Translation Studies. This is not surprising, as the principle of ambivalence informs both its composition and its conversation with its reader. Nevertheless, a positive step toward a more productive conception of surface translation was accomplished by Jean-Jacques Lecercle (1990), who defined it as a form in extremis of linguistic interference or mixing. Guided by this conception, I would argue here that the practice is in all respects identifiable with the Classical and Medieval ornamental style known by art history as the "grotesque." This is the first study to identify surface translation with the grotesque. Five specific points of comparison are leveraged here: 1) Both surface translation and grotesque art are created through the proscribed mixing of incompatible materials; 2) Both are peripheral art forms involving play with margins; 3) Both aspire toward the "perverse," "comic," and/or "monstrous" in their mixes; 4) Both tend to be explained as the product of impulsive thinking; 5) The experience that these mixtures are designed to produce is "ambivalence."
\end{abstract}

Keywords: surface translation, homophonic translation, grotesque, language mixing, macaronic writing, disguise, wordplay

\section{Résumé}

Souvent citée par les théoriciens pour des raisons contradictoires, la «traduction de surface» a un statut ambivalent en traductologie - chose peu étonnante étant donné que cette forme eccentrique-comique de traduction se veut "ambivalente» autant dans sa composition que dans sa lecture. Cependant, la théorie a marqué des progrès vers une meilleure compréhension de la traduction de surface au moment où Jean-Jacques Lecercle (1990) l'a conçue comme une forme in extremis d'interférence linguistique. Je me laisserai orienter par cette conception en proposant ici que cette pratique serait en tous points comparable au style ornemental classique et médiéval nommé "grotesque» par l'histoire des beaux-arts. Je 
présente ici la première étude traductologique à inscrire la traduction de surface dans la tradition du grotesque. Les points de comparaison sont au nombre de cinq: 1) la traduction de surface et les représentations dites "grotesques» sont créées par le mélange proscrit de matériaux incompatibles; 2) les deux impliquent, en plus, la notion d'une marge et d'un jeu centre-périphérie; 3) les deux sont informés par l'esthétique du comique, pervers, monstrueux; 4) les explications qu'ils génèrent sont fondées presque sans exception dans l'automatisme du langage et de la pensée; 5) les deux priorisent manifestement une lecture dans «l'ambivalence».

Mots-clés: traduction de surface, traduction homophonique, grotesque, mélange linguistique, écriture macaronique, déguisement, jeu de mots

Uncanny in the fullest sense of the word, "surface translation" is at once estranged and at home within Translation Studies. A glance at its conflicting uses in theory attests: on the one hand, it is described as a kind of marginal experimentation rooted in language play and pitted resolutely against traditional translation practices (Robel, 1973; Roubaud, 1973; Brisset, 1985). ${ }^{1}$ Yet on the other hand, it is acknowledged by even the most norm-oriented of models as having always oddly belonged within the spectrum of traditional practices (Chesterman, 1997, pp. 56-61). ${ }^{2}$ Not merely conflicting, these occasional theoretical treatments are also provisional, marked by a reticence to engage fully. Arguably no other type of translation has ever been so demonstrably traditional while being at the same time unfathomable as such. ${ }^{3}$ The critic cannot be blamed, however: surface translation's ambivalent position in theory is due largely to the ambivalence pervading its composition, informing its function-making it "grotesque."

1. Further, this idea of a one-off experiment-a prank of sorts?-is reinforced by the fact that many translators and scholars are altogether unfamiliar with the practice, and when finally initiated are often left bewildered.

2. Descriptive Translation Studies is not "normative" in the regulatory sense used by postmodern theory, Chesterman argues (1997,pp. 59-61). It is not in the business of enforcing traditional modes of inter-linguistic versioning based on the equivalency model, but rather of simply accounting for the entire spectrum of re-writing activities commonly called "translation." Surface translation, he points out by way of example, is certainly not traditional; nevertheless, DTS has always acknowledged it because it falls within this spectrum.

3. For Lefevere (1975, pp. 20-26), "phonetic translation" stands as the first of seven classic strategies for translating poetry, for example; however, his examination of homophony in the context of the Zukofskys' Catullus (1969) is tempered by the same reticence found in Chesterman. 
This study is about surface translation and the pictorial art form known as "the grotesque" (Kayser, 1981; Bakhtin, 1984; Edwards and Graulund, 2013), which is defined in the history of fine arts as the mixing of incompatible bodies for the purpose of creating monsters (Kayser, 1981; Bakhtin, 1984). The few poetry and translation scholars who are beginning to pay close attention to surface translation are proceeding with caution. They are attempting to find for it a place within a genealogy of ancestral artistic practices. I will argue here that Jean-Jacques Lecercle has greatly aided in this pursuit by proposing to view surface translation as a mode in extremis of mixing incompatible language materials - a perspective formulated briefly in The Violence of Language (1990, p. 71). This idea of a compression of language's sensible forms brings surface translation to the threshold of grotesque stylization as we observe it in Classical and Medieval ornamental art, and as we discover it more consequently defined during the Italian Renaissance (Barasch, 1971).

I propose to begin crossing this threshold with the help of this comparative study, which will alternate between the properties of surface translation and those of grotesque painting ${ }^{4}$ in hopes of bringing the two into meaningful dialogue along five points of convergence: 1) Both surface translation and grotesque art are created through the proscribed mixing of incompatible materials; 2) Both are peripheral art forms involving play with margins; 3 ) Both aspire toward a certain "negativity" in their mixes, opposing the "perverse," "comic," and/or "monstrous" to an orthodox form in whose periphery they are developed; 4) The type of formal association at work in these mixtures tends to be explained as the product of impulsive thinking, of an estranging organic principle at work in thought and language; 5) The mental event that these mixtures are designed to produce is "ambivalence," understood both in its rational sense of a form interpretable as more than one category of phenomenon at once; and in its affective sense of a

4. I hope that it will become clear soon enough that if I am using a plastic art form on which to base an explanation of an essentially linguistic and translational event, it is because surface translation prioritizes language's plasticity rather than its lexical, grammatical, or semantic properties. Required for any fruitful discussion of this type of translation, then, is the suppositio materialis, the assumption of language as a sensible form, a phonetic delineation meeting the ear as a pictorial one meets the eye. 
tension and apprehension that arise when an ordering principle has failed, when a phenomenon cannot be readily categorized.

As I proceed through these five points of convergence, I will be alternating between the two objects under examination here: the pictorial grotesques of painting and the linguistic grotesques of surface translation. Because this is a study that is primarily about translation, but which embarks on a comparative line of inquiry, I will deal with point 1 by comparing surface translation (first) and grotesque painting (second) in quick alternation. Then, I will deal with points 2 through 5 in a way that affords the greatest possible continuity to each object: points $2(\mathrm{a})$ through $5(\mathrm{a})$ will address the pictorial grotesques of painting predominantly; and then points 2(b) through 5(b) will address the linguistic grotesques of surface translation, where proscribed mixing assumes the nature of disguise.

\section{Mixing In Extremis}

Who are the surface translators, then, and what do they do, precisely? They form a group whose work follows the model of German poet Ernst Jandl's Oberflächenübersetzung ("surface translation") (1968, p. 51). There are five noted exemplars of the practice: Jandl himself (1968), who translates from English to German; the American foreign language professor Howard Chace (1956), who is the only one in this group to translate intralinguistically (English-English) and therefore to lean more toward something we might call "surface transformation"; and three other American translators working from English to French-the voice-over and dialect actor Luis d'Antin van Rooten (1967), the American free-lance writer Ormonde de Kay (1980), and finally the British educator John Hulme $(1981,1985)$.

Their translations are designed, I would argue, to trigger within the seasoned bilingual or polyglot a memory of the child's epistemological progress in language ${ }^{5}$ - specifically, the

5. There is another sub-set of the practice typified by the versions of Louis and Celia Zukofsky (1969) and David Melnick (1983), which I refer to as "erotic-esthetic" because their orientation is not epistemological but rather empathetic. Both the Zukofskys' Catullus and Melnick's Men in Aïda are more concerned with sensual modes of channeling the source-text form rather than childhood modes of making sense of it. This orientation is evident not only in their prefaces but also in their choice of source text and their eroticizing treatment of it. 
primary operation of figuring correct language form out of the noise of the speech signal. Never is this operation more subject to the affects associated with accuracy and error-tension in the process, naïve delight and pride of discovery in correctness, comic deflation in misrecognition-than in the formative years of language learning, either those of childhood or of secondlanguage acquisition, which in many ways bring us back (at least linguistically) to the naive position of a child. Our translators' choice of source materials attests: Ernst Jandl creates a German version of Wordsworth's "My heart leaps up," a poem about prolonging childhood joys of discovery through adulthood. The others work with childhood verse forms and narratives as well, and also with readily quotable folk poetry and canonical school poetry. Their translations, then, are sophisticated siren calls to both the imprinted verse forms buried deep in memory, and to the childhood affects associated with mastering language itself.

Surface translation is an extreme form of homophonic translation. Its art is to disguise a text in homophones from another language. The works of D'Antin van Rooten, de Kaye, and Hulme, for example, begin by assuring the reader that what follow are original French-language poems, arcane in formulation and therefore glossed extensively with expert commentary. Here is one of D'Antin van Rooten's poems from Mots d'heures: gousses, rames (1967):

Lit-elle messe, moffette, ${ }^{1}$

Satan ne te fête,

Et digne somme cœurs et nouez.

À longue qu'aime est-ce pailles d'Eure.

Et ne Satan bise ailleurs

Et ne fredonne messe. Moffette, ah, ouais! ${ }^{2}$

${ }^{1}$ Moffette. Noxious exhalations formed in underground galleries or mines.

2 This little fragment is a moral precept addressed to a young girl. She is advised to go to mass even under the most adverse conditions in order to confound Satan and keep her heart pure until the knot (of marriage) is tied... (Rhyme 10) ${ }^{6}$

6. There are no page numbers in any of these collections; rather, the rhymes are numbered sequentially. 
Of course, what we have here is really a work of unlikely bricolage following an algorithm of homophony: words and phrases are selected from the French language paradigm and sutured together from left to right for the purpose of synthesizing an end text that approximates loosely the sound pattern of the English-language source:

\author{
Little Miss Muffet, \\ Sat on a tuffet, \\ Eating some curds and whey. \\ Along came a spider \\ And sat down beside her \\ And frightened Miss Muffet away \\ (traditional)
}

The idea, of course, is to figure out the end text's dual identity without prior reference to the Anglophone source, which can be found annexed at the end of the collection. At some point, with enough stimulation from reading out loud, the memory of the source emerges into consciousness, and there is a eureka feeling accompanied by a comic sense of mental regression as the reader shifts suddenly from one cognitive frame into another-from an uncomfortable struggle with an indecipherable French language complexity (pretending to be high poetry, poetry for the scholar, for the philologist) into a rote verse form already long familiar.

When examining a specimen such as this, we are better served if we see beyond poetic and popular framings. The term "surface translation" is an epistemological metaphor. It orients our conception of this practice quite naturally toward the well-known analogy of "carrying something over"-in this case a detectable sound pattern, the phonetic "surface." Such a metaphor has the power to fixate us upon the idea of a detectable similarity in sound, and upon the comic distortions arising from it ("Little Miss Muffet" with its new, Clouseauesque French accent, for example). This similarity, however, is the effect of an underlying structural disposition that has little to do with a transfer of any kind. It is upon this underlying disposition that the critic's conception of surface translation is more productively founded, I would argue here. 
Jean-Jacques Lecercle (1990) points us in the right direction when he explains surface translation as a mode of mixing languages to an extreme degree. A compression or conflation of languages, then, rather than a mapping over of sound, is what we are presented with here. The idea of "degree" is crucial because Lecercle uses language mixing of a "lesser degree" to make his point. He begins with a type of language mixture that is far more familiar: simple code switching. His example is a mix of German and Latin in a sentence from Heidegger's Über den Humanismus (On Humanism):

Die eigentliche romanitas des homo romanus besteht in solcher humanitas. (quoted in Lecercle, 1990, p. 71)

[The romanitas that is particular to the homo romanus consists in such humanitas.]

Two features of Heidegger's sentence are immediately clear: first, there is the preservation of a dominant vernacular's grammaticality. The interference of Latin elements is primarily at the lexical level, and does not extend to the point where it compromises the grammar of the German in which the text is obviously written; secondly, the Latin is mixed into the German diachronically and discontinuously. In other words, the reader is never in more than one language at the same time. ${ }^{7}$

In a surface translation, however, the two features presented above- the grammaticality of the version as well as the temporal distribution and continuity of mixed elements-display the consequences of a language mixture that has become too pervasive and infrastructural for comfort. Here is John Hulme's translation of William Blake's "The Tyger”:

7. These same precise criteria of "lesser mixing" apply to the comic poetic form known as "macaronic writing"-another term that we would like to avoid confusing with surface translation. Indeed, Belgian historian Joseph Octave Delepierre spends the better part of his encyclopedic work Macaronéana (1852) insisting on the specific structural properties of macaronic writing: 1) a grammar firmly rooted in a developing Medieval vernacular (Italian, French, German, English); and 2) lexical elements from other languages (primarily Latin) that are mixed in, as we see in Lecercle's example. 
Tailles guerre, ${ }^{1}$ tailles guerre, beurre naine brailles-te ${ }^{2}$

Un deux foreuse; t'oeuf de n'ailles-te?

ou ôter mort ta lande or ail. ${ }^{3}$

Coude frais ${ }^{4}$ ma taille fière foule si; mettre- $y^{5}$

1 "War waists." A popular name for the Paris fashions during the 1870-71 siege. (cf. "to tighten one's belt").

${ }^{2}$ To brawl. A female dwarf arguing over some butter is compared to a drilling machine.

${ }^{3} \mathrm{He}$ wishes she would go away with her egg, or that death would take her off to her "heathland" of golden garlicpresumably the Côte d'Or, whose gastronomic delights include snails in garlic butter.

4 "Cool elbow." A slightly warmer version of the cold shoulder.

5 "Put it there!" She says that she is proud of her waist-line in any crowd and invites him to shake on it.

(Hulme, 1985, poem 24)

Compare the English:

Tiger, Tiger, burning bright,

In the forests of the night.

What mortal hand or eye

Could frame thy fearful symmetry!

(Hulme, 1985, annexed)

The first thing that we notice is that the French-language end text is grammatically and linguistically unhinged. It is not quite gibberish, but it certainly displays localized drifts into a-grammaticality. The language in which it is written is also an open question: is it simply an iteration of the Anglophone source text? Can we make sense of it strictly as a piece of writing in French? As far as the temporal distribution of the mixed elements is concerned, it is synchronic: every element of text, both on the lexical and grammatical axes, is presented simultaneously in both languages of the mix, creating the sense of an impossible continuity between English and French language materials. We just described code switching as a mix at the lexical level, as a Latin lexis intruding occasionally into Heidegger's German grammar. Surface translation mixes at a significantly deeper structural level: 
the morpho-syntactic level, specifically. Both languages of the mix are meshed inextricably on the phono-articulatory inside of the morpheme.

\section{The Formal Property of the Grotesque: Proscribed Material Participation}

What we have here is a thicket, where the sensible forms of the two languages involved have been allowed to inter-penetrate and merge in a way that is natural from a purely material perspective (suppositio materialis), yet proscribed by the rational and symbolic orders. Our translators are using perceived similarities between the "bodies" of words, between their sound structures, for the purpose of merging them. And in so doing, they are allowing words to push beyond their acceptable confines. /Tiger/ has a powerful proclivity toward its French-language counterpart /tailles guerre/ strictly by virtue of physical resemblance. The two bodies are made to merge. The French-language body /tailles guerre/ both contains and extends /tiger/, allows this English-language body to become itself again materially, formally, and semantically, and at the same time to become something more-something in excess to itself (again materially, formally and semantically), and therefore something proscribed. In this process of bodily amalgamation and extension, /tiger/ loses all semblance of univocal interpretability, becomes loaded with absurd alternative connotations (the glosses), and of course raises affect from the reader: ambivalence, humour, perhaps disgust.

I have just identified in the context of surface translation the defining formal property of "the grotesque." "Grotesque" is a term of art history (Thomson, 1972; Edwards and Grauland, 2013). ${ }^{8}$ It refers primarily to a style of composition in painting and then in literature, but of course has been so extended as to become synonymous with the affect that the style is designed to invoke. It means, quite literally, "from the cave" (Italian "grotta"), "art from the underground." The two principle historical accounts

8. These two works belonging to two iterations of the "Critical Idiom" series are a good initiation to the concept and tradition of the grotesque. They are testament, as well, to the art form's relevance in contemporary culture: Edwards and Grauland's work (Routledge's The New Critical Idiom series) articulates the evolution of the concept's use in critical discourse in the time lapsed since Thomson's work (the original The Critical Idiom series). 
(Dacos, 1969'; Barasch, 1971 ${ }^{10}$ ), as well as all subsequent concepthistorical accounts (Kayser, 1981'11; Bakhtin, 1984 ${ }^{12}$ ), take us back to excavations that occurred in Rome around 1480, where Renaissance antiquarians discovered deep under the city what would turn out to be the converged ruins of three historical structures: Trajan's thermae (built $104 \mathrm{CE}$ ), Titus's thermae (built $81 \mathrm{CE}$ ), and most importantly Nero's Domus Aurea, the decadent palace that he had built four years before his death in $68 \mathrm{CE}$.

The "House of Titus" - or so antiquarians knew it until the $19^{\text {th }}$ century, when the full extent of the discovery became clearwas a labyrinth of chambers and passageways whose ceilings and walls displayed compartments of painted pastoral scenes with ornamental fantasies filling their margins. In these marginalia, human figures merged with animal, vegetable, and wire forms with a disconcerting continuity to produce delicate, meandering monsters not reducible to a single discrete form. Rather, they were designed for sprawl, every facet and angle of every figure providing a point of onset for some other form to mix with and accrue from. And so they reached out like over-growing vegetation from the peripheries of featured paintings to spaces beyond-a remedy,

9. An excellent archeological and pictorial account of the digs and of the paintings discovered there.

10. The best history of the term "grotesque," and its extension over the last five centuries. Barasch's work is also the best gateway into the use of the term in Anglophone letters.

11. The German literary critic Wolfgang Kayser wrote the first of the late $20^{\text {th }}$ century's two seminal works on the grotesque. His work follows the evolution of the term and the style from its coining during the Roman excavations through its parallel evolution in painting and letters-with a concentration in German letters: Romanticism, Sturm und Drang theatre, Dada, and Surrealism. Kayser is credited with a conception of the grotesque oriented toward the negative pole - the uncanny and nightmarish.

12. Mikhail Bakhtin wrote the second seminal work on the grotesque. This work is his doctoral dissertation. The "grotesque," and more specifically its development into the concept of the "grotesque body" as it manifests in Rabelais's satire, is one of the two leading concepts of this work, the other being the "carnival" and the "carnivalesque." The latter gained a great deal of currency in the cultural theory of the 1990s, while critics remained largely silent on the subject of its vital contextualization within the concept of "the grotesque body." Bakhtin is credited with a conception of the grotesque oriented toward the positive pole-the principle of merging and re-combining materials for the sake of regeneration, re-growth, and renewal. 
perhaps, for the "horror vacui." These sprawling, mixing bodies (grottesche) inspired the imitative style that was soon covering the pilasters of the Vatican and being communicated by the Italian masters to the rest of Europe.

"Grotesques," then, were nearly synonymous with other closely related forms of Classical and Medieval ornamentation: scrollwork and arabesques, decorative painting and sculpture on building exteriors and interiors, manuscript illumination, etc. Their one distinguishing characteristic, however, was the surplus of affect that they provoked in their monstrous indeterminacy (capricious, fantastic, comic, or repellent) or their erotic licentiousness (a trait pertaining naturally to the principle of illicit material conjuncture). The following photograph (Figure 1) is from the façade of the City Hall in Assisi, Italy (Piazza del Comune, adjacent to Santa Maria sopra Minerva, a pagan temple turned church): a sigmoid wire-woman hangs her hair forward curiously; a canine extends an avian leg toward a priapic equine, which appears to become canine again in its lower half.

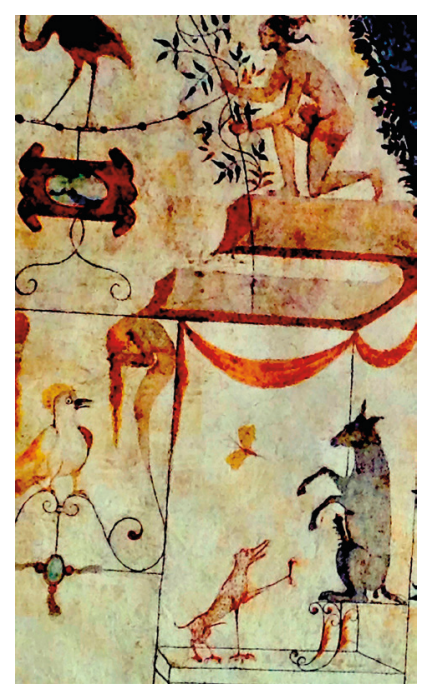

Figure $1^{13}$

13. Many thanks to my colleague Charles Le Blanc (http://uottawa.academia. edu/CharlesLeBlanc) for taking this photograph on site in Assisi. 
Indeed, the best way to relate grotesques to other Classical and Medieval ornamental forms would be subordination: they form a sub-class of the monstrous cited within superordinate practices like scrollwork, building ornamentation, and manuscript illumination. What really happened in the grotta of the Domus Aurea, then, was not so much the discovery of a new art form as it was a renewed consciousness of the more estranging and affectively galvanizing loci of Classical and Medieval ornamentation, and the coining of a term suitable for evoking them.

Of course, the designation "grotesque" has extended beyond its origin in the plastic arts, and is now applicable to any art form (any perceptible form, for that matter). It is most broadly defined as a specific "formal property" designed to arouse a specific "mental event" (Galt Harpham, 1982, p.27). The formal property, as we have just discussed, is "proscribed material participation," and the mental event is "ambivalence." As far as the former is concerned, we can connect at all points the type of opportunistic material connection forged in surface translation with the hybridizing style of grotesque art. The operation follows two simple principles: 1 . Break the rules of order and autonomy that keep bodies and systems of bodies separate (in surface translation, these are the rules against interference, which normally keep the signifiers of different language systems apart); 2 . Connect and merge bodies wherever they offer material purchase (in surface translation, homophony provides this purchase). Bakhtin terms a "grotesque body" one pursuing precisely these principles:

The grotesque is interested only in...that which protrudes from the body, all that seeks to go out beyond the body's confines. Special attention is given to the shoots and branches, to all that prolongs the body and links it to other bodies or to the world outside. $(1984$, p. 316)

What Bakhtin articulates here is a mixing principle based predominantly upon the topographic and sensory proclivities of bodies - convexity goes into orifice:

All these convexities and orifices have a common characteristic; it is within them that the confines between bodies and between the body and the world are overcome: there is an inter-change and an inter-orientation. (p. 317) 
Grotesque bodies are licensed to connect and mix with other bodies at whatever fitting part offers purchase, and by whatever serendipitous inter-action. One body reaching out to contain and extend the line of another, and to challenge the rational order that would keep them separate- such is the definition of grotesque form.

\section{2(a) The Peripherality of Grotesque Painting}

Grotesque art is peripheral-a liberal, experimental framework speaking against the orthodox compositional center of a painting, text, or building. In other words, it generates a margin where the serious and the non-serious conflict comically and interact. We know, of course, that with Bakhtin (1984) this clashing topography from the domain of the fine arts-suggestive of a kind of mise en abyme where a chaotic framework is presumed to be a comic version/inversion (caricature, parody, or even satire) of the ordered work within-becomes extended analogically into the socio-cultural realm (Camille, 1992). ${ }^{14}$ The monsters framing Classical paintings, Medieval manuscripts, and the interiors of sacred buildings have become analogous with the minor or fringe cultures encroaching in the periphery of powerful cultural centers. Folk humour and carnival ritual, for example, are Bakhtin's margin - a space where an outlying and disenfranchised folk culture meets a dominant center of orthodoxy in a creative experimentation involving material excess and comic inversions of the feudal social order.

Clashes between the center and the periphery of artistic representation have come to mirror, then, clashes between the center and periphery of culture. For support of this analogy we need look no further than the low regard in which high culture held (and likely continues to hold) grotesque representations.

14. The scholarly complement to Bakhtin is Umberto Eco's historical fiction (and pseudo-translation) Il nome della rosa (1980). This detective novel does its best to suspend both disbelief (as all fiction does) and belief (in any truth value it might possess as scholarly discourse); however, this does not prevent it from offering one of the more illuminating accounts of the Dulcinian heresy (1240-1307), a popular uprising on the radical fringe of the Franciscan Friors Minor, which threatened the latter's position with respect to the papal centre of orthodoxy. All of this is accomplished with striking and consistent analogy with the topography of manuscript and architectural grotesques. 
The voice of orthodoxy dominating in the critical literature on the grotesque, and informing the position of Renaissance high culture in matters of artistic and architectural representation, is Augustan architect Marcus Vitruvius Pollio (80-70 BCE - circa $15 \mathrm{CE})$, from whom scholars have derived the "Vitruvian view" (Battista Alberti, 2011, 1988; Vitruvius, 1998; Barasch, 1971, pp. 25-32). According to Vitruvius and the Pythagorean tradition that he represents, art and architecture should aspire to emulate the perfect rational, mathematical design believed to inform Creation. ${ }^{15}$ This means striving toward artistic representations that are perfectly proportional both within themselves and with the real-world objects that they imitate.

Of course, the type of chaotic mixture displayed by grotesques is antithetical to this dictate. Vitruvius comments:

But these which were imitations based upon reality are now disdained by the improper taste of the present. On the stucco are monsters rather than definite representations taken from definite things [...] Candelabra uphold pictured shrines and above the summits of these, clusters of thin stalks rise from their roots in tendrils with little figures seated upon them at random. Again, slender stalks with heads of men and of animals attached to half the body... (Vitruvius, 1998, p.105)

He then proceeds with an account of the mathematician Lycimnius, who characterizes those who over-indulge in grotesque mixing as lacking an abstract (read "true mathematical") sense of the relationship between sensible forms. There is something mentally regressive, he maintains, in allowing bodies and the systems ordering them to simply collapse together in representation. Vitruvius echoes Lycimnius with a devaluing dig at some outlying and distant cultural other situated beyond the margin: "If we approve in pictures what cannot justify itself in reality, we are added to those cities which, because of such faults, are esteemed slow witted." (Vitruvius, 1998, pp. 105-109)

\section{3(a) The Negativity of Grotesque Painting}

Condemnation, then, seems to be part and parcel of the grotesque esthetic. If in most art of the Classical and Medieval worlds we find chaotic marginalia framing some orthodox center of

15. See Walter Isaacson's recent biography of Leonardo da Vinci, specifically the chapter "Vitruvian Man"(Isaacson, 2017, pp. 140-159). 
representation, then "grotesque" is the descriptor reserved for those depictions of the chaotic that risk leaning toward the negative pole in their reception - the unsettlingly "ugly" (in a comic and/or repellent way), "perverse," or "monstrous." Evident here, of course, is an intellectually uncomfortable but nevertheless unavoidable component of affect-driven value judgment.

Art historian Michael Camille (1992), for example, is troubled enough with the "negatively loaded" (p.12) term "grotesque" to suggest emphatically that it should not be used in reference to manuscript illuminations, even the most comically unhinged. Such scholarly aversion to the term is evidence not only of its power to provoke, but also, I would argue, of its ability to compromise intellectual distance to the point where there arises confusion between the "negativity" that is a defining part of the grotesque's technical execution and esthetic, and another more political type of "negativity" arising in academic discourse where we meet with the scholar's broader concern that the term might generate biases among his or her fellow scholars, and make the art form less attractive to study.

It has proved difficult, however, to find any alternative term that would mitigate this broader political concern without also undermining the art form's defining negativity. These drawings, paintings, and sculptures are "negative" first and foremost because they are pitted against a positive pole of orthodoxy implicit in the center of the frame. Where other ornamental arts add a supplemental splendor (positive to positive), grotesques add the shadow that clarifies through a contrasting and subversive sensibility (negative to positive). Encompassing this fundamental negativity necessarily, all alternative terms naturally assume a negative load of their own. Camille himself, for example, leans toward a fourteenth-century precursor: "babuini," origin of word "baboon," and translatable as "monkey-business." (1992, p.)—a fine alternative, perhaps; but one cannot reasonably imagine that it somehow circumvents the negativity implicit in the term "grotesque."

\section{4(a) A Root in Impulse: Underground Thinking}

"Slow-witted" is how Vitruvius characterizes the grotesque. As it pits its monstrous admixtures against the doxa, value judgments emerge as to the mental profile of the art, the artist, and the 
culture to which both belong. Psychological explanations of the grotesque have evolved along with artistic sensibilities over the centuries. Consistently, however-whether departing from the negative biases of Classical, Neo-classical and/or Enlightenment sensibilities; or from the favorable biases of Renaissance, Romantic and Modernist ones - all roads seem to lead toward an explanation of the grotesque that is firmly rooted in impulsive thinking.

It is not my intention here to enter into the evolution of psychological concepts such as the "unconscious." Such a detour is not really needed for my purposes here, which I can accomplish by putting forward a simple idea that modern psychological and neurological research would have little problem with: thinking is not a phenomenon under the exclusive control of the will; rather, to an extent that is not yet fully understood, it simply happens to us: we undergo it biologically and neurologically like our heart beat or any other physiological function.

There is a topographical metaphor used by Arthur Koestler in The Act of Creation (1964), and I am partial to it because it harmonizes well with the literal topography of the original grotesque paintings. He refers, specifically, to an "underground" of thinking, where instinct compels us toward de-discrimination and participation - toward the proscribed mix based entirely upon the proclivities of sensible form. This is a universal topos of thinking on grotesque imagery in both painting and poetry. "Sogni dei pittori" (dreams of the painters) is the paraphrase used by Wolfgang Kayser (1981, p. 22) to describe grotesque forms across the divides of art, extending over the full range of hybridized monsters from the ornamental and capricious to the fantastic, the surreal, and the absurd. The latter are pervasively characterized in the critical literature as deriving from attempts to re-construct the imagery of dreams - those currents of thought that are uncanny to us-both intimate and familiar yet necessarily estranged.

\section{5(a) The Ambivalence of Grotesque Painting}

This underground produces its share of ambivalent forms. "Ambivalence" is the mental event that the grotesque is commonly held to generate. Definition is necessary here, as the term itself has two potential meanings, the first referring to the formal property of an object, the second to a mental state generated by this same object. An object is "ambivalent" if it displays the 
physical properties of two things at once. ${ }^{16} \mathrm{~A}$ mental state is "ambivalent" if it is caught suspended between contradictory ideas and/or emotions with respect to the object. The resulting emotion is a tension connected with the struggle of making sense of something. Depending on the interpreter's particular disposition, this tension can manifest in a number of affectsintellectual interest, mirth, or even raptness; anxiety, aversion, or even abjection.

It is to this mental state that I am referring in this final section dedicated to painting exclusively. To qualify and examine it, Geoffroy Galt Harpham recalls and extends George Santayana's (1896) classic conception of a "grotesque moment," which is an interval of understanding that suspends us between two or more contingent interpretations. It begins with the experience of estrangement that we undergo with our initial perception of a novel arrangement of material details - fur and fangs on a human face, say - and ends with the slotting of this arrangement into a typed category such as "werewolf":

When we encounter something new we ask, "What's it like?" which can be translated as, "What familiar forms can you recognize in it?" Eventually we discover the proper place for the new thing, and recognize it not only for what it is like but for what it is in itself. We have followed this process in learning to call mouse-birds "bats," horse-men "centaurs." (Galt Harpham, 1982, p. 19; my italics)

Any odd relation of formal properties can be typed. All forms, natural or imagined, that shock in their novelty are destined to become closed, ordered, and identifiable.

Galt Harpham differentiates between two questions in the passage cited above: "what is it like?" and "what is it?" The first question is phenomenological, concerned with experience; and the second rational, concerned with identification and categorization. Further, he adds the second question to the first ("not only, but also"), does not use the second question to mitigate the first or to cancel it out. This detail is rather important. We cannot assume that successful categorization necessarily has the power to alter our experience of an ambivalent object- too many people know

16. The French "ambivalence" refers primarily to this formal property of an object. 
what "bats" are, for example, but are still spooked by them. All it takes is imagination - in the truest sense of a cognitive shift from the idea to the image, from the knowledge of what something is to a fully fleshed-out impression of what something is like-and one can re-visit the grotesque moment no matter how typed or clichéd the object in question may become. In other words, the full estranging experience of grotesque forms can and often does override our comforting classification of them.

\section{2(b) The Peripherality of Language Grotesques and Surface Translation}

We have been positioned until now at the threshold of another concept that is of a piece with the grotesque's principles of material mixing and peripherality: disguise. As we proceed now from pictorial grotesques toward linguistic ones, and ultimately toward surface translation, an understanding of the marginality implicit in all forms of disguise (the monstrous included) becomes especially relevant, if only because a surface translation does not readily appear to generate a margin of its own, or to be as peripheral in nature as pictorial grotesques are.

But it most certainly does, I would argue, and it most certainly is. Surface translations are true disguises, dissimulations at the physical level—so much is certain. Further, all true disguises are by nature marginalia. They imply a de facto relationship between a central form and an elaborated exterior framework that both contains and dissimulates this form. Indeed, it seems impossible to imagine any disguise (natural or artificial) that is not in itself a collection of materials framing a body so as to appear "natural"continuous with it, emerging from it, constituting it. In other words, a disguise implies a margin whose playful purpose is never to appear as one, at least while it is deceiving us. The fact that the margin has been there all along becomes apparent when, for example, the wig of a female impersonator is removed, or the walking stick falls from the branch. The line between the true body and the well-blended accretions pertaining to the disguise is always re-constituted. The margin always declares itself.

A disguise does to the discretionary landmarks separating the margin from the center precisely what the grotesque does to all material boundary lines that it touches: it mixes them, forces a deceptive continuity between them. And therefore a monstrous 
disguise or dissimulation - a disguise with the added quality of clashing in an outlandish or comic-negative way with respect to the body from which it accrues - is necessarily "grotesque." Once again, however, deceiving through continuity does not mean collapsing the margin or diminishing its function. The latter is always there, and it makes itself known by virtue of the formal difference that we perceive between the amalgam that is the disguised object and our knowledge of this same object without its lately accrued exterior.

Language grotesques lean toward disguise, toward more extensive dissimulation in their admixtures. We observe this already within an intermediate space where pictorial forms meet and mix with graphic verbal ones. Take the following manuscript illumination from Brunetto Latini's Livres dou tresors, for example:

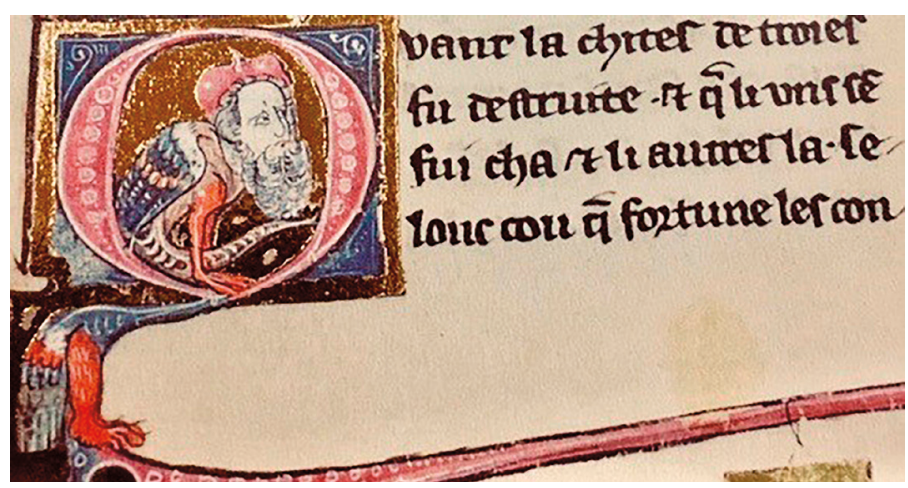

Figure $2^{17}$

Here the pictorial illumination informing the 'Q' ("Quant la cite de troies fut destruite...") does not sit placidly in the discernible margin of the text, but rather creeps inward to mix with it, to dissimulate it. The man-duck-worm figure looks to be sitting within the aperture of the ' $Q$ ' (which itself appears to be a mixture of alphabetic, simian, and avian forms); or maybe he is not merely sitting in it, but is also an extension of it, depending on how we track the line of his ambivalent posterior and lower

17. Manuscript illumination from Brunetto, Latini (1264), Li livres dou tresor. Facsimile reproduction by Turrò, Jaume, and Kiseleva, Liudmila II'inichna (book, 2 vols. 38 by $32 \mathrm{~cm}$ ), vol.1, p.15. Barcelona, M. Moleiro, 2000. Archives and Special Collections (ARCS), University of Ottawa. Rare Books. 
body. Whatever the case, the orthodox 'Q' still abides perceptibly within the comical monster that accrues from it. The letter has been overlaid, invaded and invested by the pictorial work of the margin, but this greater inter-penetration and involvement does not mitigate the reader's duty to continue observing the margin's separating function, and in so doing to extricate the 'Q' from within the thicket of the admixture.

\section{The Margin in Surface Translation}

In surface translation, of course, we are no longer in the pictorial but rather in the admixture of linguistic forms. We are no longer relying on visual cues to detect the margin constituting the framework of the disguise; rather we have to rely on aural cues and our hard-wired ability to reduce the noise of speech distortion. We are, however, performing a structural detection game that is at all points similar to that of Latini's illumination.

Surface translation offers us the different languages involved as reliable landmarks for detecting the margin. Take the following from Ormonde de Kay:

O âne fort témoigné, ${ }^{1}$

Tous forts dés chauds,

Tris tous gais de redits,

Ane fort-tous gaus. ${ }^{18}$ (De Kay, 1980, rhyme 7)

The amalgamating framework here is in French, but we cross a margin toward the inside, into an English-language infrastructure, as we retrieve the orthodox form perceptible within: "One for the money/Two for the show/Three to get ready/And four, to go" (traditional).Whichever language we are citing at the moment tells us on what side of the margin we are experiencing the poem. From the interior, the surface translation reads as English deformed. From the exterior, it reads as French-language collage susceptible to absurd glossing or even to further attempts at translation:

O thou, proven strong ass,

All strong hot dice,

Odd tricks with gossip gay,

Strong ass—all lice (De Kay, 1980, rhyme 7)

18. Compare the English: "One for the money,/Two for the show,/Three to get ready,/ And four, to go" (traditional). 
And so goes the reading of such a text-in a continuous shuttling back and forth between the orthodox form on the inside and the monstrous framework around it.

Inferring the margin within the material accretions of a language disguise is of course never straightforward work, which brings us to another characteristic that stresses surface translation's marginality: unlike any other kind of translation, which creates a stand-alone "target text," a surface translation creates what could best be described as an insufficient end text, which is virtually never published without the source text displayed in parallel or in a key at the end of the edition. The reader is consistently oriented back to the correct form inside after struggling with the framework of the disguise.

\section{3(b) The Negativity of Surface Translation: Howard Chace's "Warts"}

The fundamentally comic-negative function of the grotesqueCamille's "negative load" (1992, p.12)—would seem to apply every bit as much to surface translation as it does to painted grotesques, or to those that mix pictures with language. Linguistic grotesques, we have just discussed, have a penchant toward monstrous disguise, toward the amalgam that constitutes a comically distorted, amplified, or accented version of the orthodox form inside. Out of this same perception comes Howard Chace's comic-negative characterization of "surface transformation."

"Surface transformation" is technically identical to "surface translation," except that it is performed intra-linguistically. Howard L. Chace (1897-1982)—a professor of Romance Languages at Miami University in Oxford, Ohio from 19381965-offers us a compellingly "negative" characterization of its technique and comic result. Chace's work is Anguish Languish (1956), a collection of English-English surface transformations that use English-language homophones to create their disguises. Like the other surface translators, Chace works with nursery rhymes - "Old Mother Hubbard," for example:

Oiled Murder Harbored

Wen tutor cardboard

Toe garter pore darker born

Wenchy gut dare 
Door cardboard worse bar

An soda pore dark hat known... (Chace, 1956, p. 40) $)^{19}$

Unlike the others, however, Chace uses a metaphor of pathology and physical disfiguration to characterize his end texts. These are in an ersatz language, he argues - the titular Anguish Languish: "A word that has received a new meaning has become a wart, and when all the words in the passage have become warts, the passage is no longer English; it's Anguish" (1956, p. 11). This "wart" is of course a pun ${ }^{20}$ on "word." It evokes, embodies, and characterizes all at once the material accretions of the disguise as a disfiguring of proper English words. The words "Old Mother Hubbard," for example, sprout "warts" out of their own constituent sounds to create "Oiled murder harboured"-an end-phrase that continues to be its source phrase, yet has also become something different, something monstrous through material accretion. It has acquired some decidedly unattractive and disfiguring phonatory baggage, which has in turn created the new and undesirable connotation of being a slick, homicidal, fugitive from justice.

\section{4 (b) Surface Translation and Impulse: Sogni dei traduttori}

As we discussed earlier, there is a level at which thinking simply happens to us. The same is true for language, and Jean-Jacques Lecercle dedicates The Violence of Language (1990) to this very idea. Lecercle translates this idea of an uncanny interface with underground language into a fully elaborated concept called "the remainder," which he at one point uses in reference to surface translation. Without ever mentioning the term "grotesque" ("uncanny" emerges often enough, however), he nevertheless escorts the affect associated with this art form into the realm of linguistics via his "remainder."

19. Compare the English: Old Mother Hubbard/Went to the Cupboard/To get her poor dog a bone/When she got there/The cupboard was bare/And so the poor dog had none... (traditional).

20. Punning, of course, is a germane form of word mixing in conventional language humour. It would be unwise, however, to call surface translation simply a form of inter-linguistic punning. Even the most precursory examination of the typical pun (Delabastita, 2014) shows the use of a verbal economy that is nowhere to be found in surface translation. A pun is at best a grotesque instant, a single mixed word or phrase in the midst of an otherwise coherent narrative that sets it up and limits is potential interpretations. 
The term itself demonstrates an intriguing connection with both the ideas of marginality (the "remainder" is posited as peripheral, as outlying agencies of linguistic creation that are beyond our rational centers of attention and control) and impulse (at some level, language speaks us):

Language speaks, it follows its own rhythm, its own partial coherence, it proliferates in apparent, and sometimes violent, chaos $[\ldots]$

There is another side to language, one that escapes the linguist's attention, not because of his temporary failure or failings, but for necessary reasons. This dark side emerges in nonsensical and poetic texts, in the illuminations of mystics and the delirium of logophiliacs and mental patients [...] I have called it the remainder. (1990, pp. 5-6)

Note the affect-related language here: "violence," "chaos," "dark side." Lecercle's "remainder" is the expression of an anxiety that emerges when our sense of rational control over language is met by the equally powerful sense of an anti-rational force emerging from estranged sites of production in a language underground with resolutely materialistic proclivities. The mergers permitted within this underground follow an entirely different principle than that of the symbolic order that bends us to a belief in discrete, autonomous bodies of language such as English, French, Italian, etc. Habituated to the prescribed forms of the latter, we tend to forget that they are not naturally occurring, but are rather feats of attention, discrimination, and directed cognition.

Lecercle's object is Victorian nonsense poetry (see also Lecercle, 1994), but he does pause to connect surface translation to his concept of the remainder (1990, pp. 70-73). And at this moment, his discourse echoes Koestler's in The Act of Creation (1964):

Next to repetition, association by sound affinity [...] is one of the notorious games of the underground, manifested in dreams, in the punning mania of children, and in mental disorders...In normal, rationally controlled speech, association by pure sound is prohibited, for, if given free rein, it would destroy coherence and meaning [...]; once one tunes into the matrix of sound-associations, a number of quite idiotic puns and rhymes will invade the mind. No 
effort is required to produce them; on the contrary, when concentration flags, and the rational controls are relaxed, thinking has a tendency to revert, by its own gravity as it were, to matrices governed by more primitive rules of the game. Among these, association by sound-affinities plays a prominent part. (Koestler, 1964, pp. 314-315)

"Quite idiotic" is a telling choice of words, here: an aboveground of language control organizes a concerted and affect-loaded resistance to the underground of language instinct. There is of course nothing idiotic or primitive about the way that language works in the mind. Koestler's words do not necessarily mark value judgements, but rather assertions of control: they emerge out of the vigilance that goes into keeping language in order, into keeping things separate, be they elements in the same language system or opposing language systems. ${ }^{21}$

Of course, I do not mean to suggest that surface translation is itself the result of relaxed attention and a surrender of conscious control. Obviously, no instinctual or naturally occurring event of homophonic association would ever construct the type of extended transphonation that we have here. What I am suggesting is that surface translation is a poetic staging - not only conscious but also very deliberate, skillful and creative- that necessarily recalls in a comic way the ambivalent affect arising from such a relaxation and surrender. I view it as a conscious, poetic re-construction echoing the sogni dei traduttori, demonstrating that the impulse orienting sensible forms toward material merger is there to undo the finer pretentions of rationally ordered, individual and discrete language systems. It would seem that a conscious decision has been made to create language art where "the more primitive rules of the game" are given a maximum of operational latitude, where the language underground effectively rises to meet the reader in good humour.

21. Translators are acutely aware of this natural propensity to mix materials, which must be matched by efforts of attention exerted in the opposite direction. Cribbing, calquing, false cognates - these are all frequent beginner's errors. Indeed, in Jean Delisle's manual for translator training La traduction raisonnée (Delisle and Fiola, 2013), "la séparation des langues" is one of the four competencies consolidating the future translator's aptitude. 


\section{5(b) Surface Translation and Ambivalence}

Surface translations seemed designed to have us continually revisit our experience of them-not to know what they are, but more importantly to know what they are like: how they sound in the reading, how they generate affect, how shifts of attention and perspective multiply contingent interpretations. We might try to account for this experience by applying the "grotesque moment" or "interval of understanding" that we discussed earlier with reference to Galt Harpham and Santayana. Take Luis d'Antin van Rooten's Francophone version of "Humpty Dumpty," for example, which has to be the most cited specimen of surface translation in all of the critical literature ${ }^{22}$ :

Un petit d'un petit ${ }^{1}$

S'étonne aux Halles ${ }^{2}$

Un petit d'un petit

Ah! degrés te fallent ${ }^{3}$

Indolent qui ne sort cesse ${ }^{4}$

Indolent qui ne se mène ${ }^{5}$

Qu'importe un petit d'un petit

Tout Gai de Reguennes. ${ }^{6}$

1 The inevitable result of a child marriage.

2 The subject of this epigrammatic poem is obviously from the provinces, since a native Parisian would take this famous old market for granted.

3 Since this personage bears no titles, we are lead to believe that the poet writes of one of those unfortunate idiotchildren that in olden days existed as a living skeleton in their family's closet [...]

4, 5 Another misdirection. Obviously is was not laziness that prevented this person's going out and taking himself places.

6 He was obviously prevented from fulfilling his destiny, since he is compared to Gai de Reguennes. This was a young squire $[\ldots]$ who died at the tender age of twelve [...] (D’Antin van Rooten, 1967, rhyme 1)

22. Compare the English: Humpty Dumpty sat on a wall/Humpty Dumpty had a great fall/All the king's horses/And all the king's men/Couldn't put Humpty Dumpty/Together again (traditional). 
Interestingly enough, an interval of understanding beginning in true naivety (where the reader sincerely believes that this is an original French poem and then struggles to make sense of it as such) is almost excluded from possibility. It is important for the comic effect, however, that the reader suspend at some point his or her knowledge of the poem's identity to play at reading it as a French-language text. This is where the ambivalent nature of the French grammar can be fully appreciated, with help from the glosses. The first two lines do have grammar, propositionality even: "A little one born of a little one gets a big surprise in the Market." There is a whiff of the carnivalesque, here, of Billingsgate.

The next two lines begin to stray grammatically, but can pass as arcanely figured, becoming plausible with a little forced inference: "O, Little one born of a little one, you are missing degrees!" It gets folksier still, and the idea of a déclassement-that of the poem's protagonist (the "Little one")—begins to manifest. The fifth line, however, begins to challenge the reader's powers to infer any kind of grammaticality. The formulation is not so much a-grammatical as it foggy, oneiric-a drunkard's-dream syntax hovering somewhere between lexical collage and conventional grammar. It makes the reader want to infer, search, struggle to create sense. The more artfully executed surface translations will contain flashes of conventional target language syntax, but between such flashes there is always a drift toward a threshold of grammatical dissolution.

A second interval of understanding occurs when we are aware of the homophonic disguise in use by the translator and are attempting to identify precisely which English-language rhyme is in front of us. It is hard to imagine a more suspenseful mode of retrieval from memory than the recall of a source text's phonetic pattern based upon the repeated pronunciation of this same pattern's vaguely homophonous iteration in another language. What is in play here is an appeal to sub-conscious agencies of thought processing and to long-term memory, where the speech patterns of these verses are stored.

These agencies are for the main part automatic, inaccessible to attention even, let alone to conscious control. The best we can do is try to stimulate them into action by reading the end text out loud and repeatedly while attempting to relax the conscious controls trapping us in the French-language frame. Surrendering a 
measure of conscious control-relaxing, drifting cognitively while repeating the French-language pattern like a chant-is the only way to the solution of the puzzle (barring cheating, of course, and turning to the English at the back of the book). When the latter comes to us, it is an uncanny experience: we remember the rhyme well before we are able to articulate it to ourselves consciously. Recognition begins in the hidden agencies just discussed, and fully conscious recall lags behind. This experience of limbo, as we hover between a realized yet still subliminal memory (it is there, on the tip of the tongue) and the latter's full emergence into consciousness makes surface translation the unique staging of a type of déjà vu (déjà entendu).

A third and final interval arises when we have identified the rhyme and are attempting to compare the French against the English source. The French-language text quite often does not reconcile with the sounds of the English-language rhyme. We cannot expect full closure even at this level. Indeed most of the time, the French-language sound pattern is just similar enough to jar the vaguest memory of the English-language one, but is not similar enough for us to feel comfortable calling the two patterns homophonic. The visual composition and boundaries of words in the French writing - as well as their auditory composition and boundaries in oral performance - trap us in the exterior of the disguise, orient us away from our phonetic memory of the source text's English. They not only bar access to the English inside, but they also pull us away from it after it has been detectedthey extend and distort the English rhyme to the point where we are caught in the maddening situation of having to entertain the reality that this French-seeming construction is its Englishlanguage source text, and is not.

I will conclude here by re-joining the matter of my introduction: surface translation's place and status within the models of Translation Studies. The orientation of this study leads me to think that this place and status need not remain as ambivalent as the practice itself. The conception of the latter as a mode of mixing instead of transferring language sounds anticipates a potentially fruitful dialogue with Translation Studies' already plentiful literature on translation, language mixing, and humour (Chiaro, 2010). Surface translation's current disconnect from this discourse is due largely to the fact that the only modes of 
language mixing that have fallen under the critical lens thus far are the more conventional modes of punning (Delabastita, 2014) and/ or code switching, with its burlesque exaggeration in macaronic writing (Charron, 2004). As far as surface translation is concerned, its status as a language mixture is difficult if not impossible to qualify and elaborate without a grounding in grotesque art and its theories. With the latter, however, a powerful tool is acquired, and both the formal properties of surface translation and the mental event it invokes acquire a certain transparency-no small accomplishment given the deliberate opacity of this comic form.

\section{References}

Bakhtin, Mikhail (1984). Rabelais and his World. Trans. Hélène Iswolsky. Bloomington, Indiana University Press. [First published (1965). Tvorchestvo Fransua Rable. Moscow, Khudozhestvennia literatura.]

Barasch, Frances K. (1971). The Grotesque: A Study in Meanings. Paris/The Hague, Mouton.

Battista Alberti, Leon (2011). On Painting. Ed. and Trans. Rocco Sinisgalli. New York, Cambridge University Press.

Battista Alberti, Leon (1988). On the Art of Building. Trans. Joseph Rykwert, Neil Leach, Robert Tavernor. Cambridge, MIT Press.

Brisset, Annie (1985). "La traduction comme transformation paradoxale.” Texte, 4, pp. 191-207.

Camille, Michael (1992). Image on the Edge: The Margins of Medieval Art. London, Reaktion Books.

Chace, Howard L. (1956). Anguish Languish. New Jersey, Prentice Hall. Charron, Marc (2004). “Le Don Quijote en espanglais: réflections autour de la traduction d'Ilan Stavans." TTR, 17,1, pp. 183-194.

Chesterman, Andrew (1997). Memes of Translation: The Spread of Ideas in Translation Theory. Amsterdam/Philadelphia, John Benjamins.

Chiaro, Delia, ed. (2010). Translation, Humour and Literature. London, Bloomsbury Publishing.

Dacos, Nicole (1969). La découverte de la domus aurea et la formation des grotesques à la Renaissance. Studies of the Warburg Institute, vol. 31, London, Leiden E. J. Brill.

D'Antin van Rooten (1967). Mots D'Heures: Gousses, Rames: The d'Antin Manuscript. New York, Grossman Publishers.

De Kay, Ormonde (1980). N'Heures Souris Rames: The Coucy Castle Manuscript. New York, Clarkson N. Potter, Inc.

Delabastita, Dirk, ed. (2014). Essays on Punning and Translation. London/ New York, Routledge. 
Delepierre, Octave (1852). Macaronéana, ou mélanges de littérature macaronique des différents peuples de l'Europe. Paris, G. Gancia, libraire.

Delisle, Jean et Marco A. Fiola (2013). La traduction raisonnée. Manuel d'initiation à la traduction professionnelle de l'anglais vers le français. $3^{\mathrm{e}}$ éd. Ottawa, Les Presses de l'Université d'Ottawa.

Eco, Umberto (1980). Il Nome della Rosa. Milan, Bompiani. [English translation by William Weaver (1983). The Name of the Rose. New York, Harcourt.]

Edwards, Justin D. and Rune Graulund (2013). Grotesque. London/New York, Routledge.

Galt Harpham, Geoffroy (1982). On the Grotesque: Strategies of Contradiction in Art and Literature. Aurora, The Davies Group Publishers.

Hulme, John (1981). Mörder Guss Reims: From the Original Manuscript of Professor Leberwurst. London, Angus and Robertson. [Published simultaneously in New York, Clarkson N. Potter, Inc.]

Hulme, John (1985). Guillaume Chequespierre and the Oise Salon: An Anthology Selected E Edited by John Hulme. London, Angus and Robertson.

Isaacson, Walter (2017). Leonardo da Vinci. New York, Simon \& Schuster. Jandl, Ernst (1968). Sprechblasen. Hamburg, Luchterhand.

Kayser, Wolfgang (1981). The Grotesque in Art and Literature. Trans. Ulrich Weisstein. New York, Columbia University Press. [First published (1957). Das Groteske: seine Gestaltung in Malerei und Dichtung. Oldenburg/Hamburg, Gerhard Stalling Verlag.]

Koestler, Arthur (1964). The Act of Creation. New York, The Macmillan Company.

Lecercle, Jean-Jacques (1990). The Violence of Language. London/New York, Routledge.

Lecercle, Jean-Jacques (1994). Philosophy of Nonsense: The Intuitions of Victorian Nonsense Literature. London/New York, Routledge.

Lefevere, André (1975). Translating Poetry: Seven Strategies and a Blueprint. Amsterdam, Van Gorcum.

Melnick, David J. (1983). Men in Aïda. Introduction by Sean Gurd. San Francisco, Uitgeverij Publishing House.

Robel, Léon (1973). “Translatives.” Change, 14, pp. 5-13.

Roubaud, Sylvia (1973). "Mots d'Heures, Gousses, Rames." Change, 14, pp. 97-111.

Santayana, George (1896). The Sense of Beauty. New York, Charles Scribner's sons.

Thomson, Philip (1972). The Grotesque. London, Methuen and Co. Ltd. 
Vitruvius, Marcus V. Pollio (1998). On Architecture: Books 6-10. Trans. Frank Granger. Cambridge, Harvard University Press.

Zukofsky, Louis and Celia Zukofsky, trans. (1969). Catullus. London, Cape Goliard Press.

Ryan Fraser
School of Translation and Interpretation

University of Ottawa

70 Laurier Avenue East, Room 401

Ottawa (Ontario) K1N 6N5

CANADA

ryan.fraser@uottawa.ca 